\title{
MOŽNOSTI ARCHEOLOGIE PRO POZNÁNÍ PRODUKCE POTRAVIN V POZDNĚ STŘEDOVĚKÉ PLZNI
}

\author{
JIŘÍ ORNA - VERONIKA DUDKOVÁ
}

\begin{abstract}
Abstrakt: Přispěvek nastiňuje možnosti archeologie pro poznání produkce potravin v pozdně středověké a raně novověké Plzni. Představeny jsou archeologicky získané doklady zemédělství nejen v prostoru vlastního královského města, ale také v jeho hospodářském zázemí. Především ze zásypů odpadních jímek se podařilo ziskat doklady potravinářských řmesel - rybolovu a sladovnictví. Význam odpadnich jímek pro poznání tohoto segmentu každodenního života $v$ pozdně středověkém městě nespočívá pouze $v$ nálezech artefakti̊, ale zejména $v$ možnosti ziskáni ekofaktů, které maji pro poznáni produkce potravin vysokou výpovédní hodnotu.
\end{abstract}

Klíčová slova: Plzeň - odpadní jímky - remesla - potraviny - zemědělství.

The potential of archaeology in the study of the production of foodstuffs in Plzen̆ in the late Middle Ages Abstract: This contribution outlines the potential of archaeology in the study of the production offoodstuffs in Plzeň in the late Middle Ages and the early modern age. It presents archaeological evidence of agriculture, in the royal town of Plzen̆ as well as in its hinterland. The fills of refuse pits yielded evidence of foodstuff crafts such as fishing and malting. The importance of refuse pits for the study of this segment of everyday life in the late medieval town does not only lie in the finds of artefacts but, in particular, in the acquisition of ecofacts with great informative value for the study of foodstuff production.

Key words: Plzeñ - refuse pits - crafts - foodstuffs-agriculture.

\section{Úvod}

Na konci 13. století vzniklo poblíž soutoku řek Radbuzy a Mže královské město Plzeň. Přesunula se sem zřejmě většina obyvatel Staré Plzně, dosavadního mocenského centra západních Čech, další noví měšt’ané pak pravděpodobně přišli z již existujících královských měst Českých Budějovic, Stř́ibra a Klatov a z poddanských měst Touškova a Dobřan (Vojtíšek 1920, 8). Uvnitř hradeb bylo postaveno 283 (Strnad 1889, 250) až 290 (Strnad 1909, 56) domů, které obývalo více než 3000 lidí (Strnad 1889, 252). Dalších 69 domů a 25 dvorů je doloženo na předměstích (Strnad 1889, 250). Celkem se tedy předpokládá, že ve městě a na předměstích sídlilo zhruba 4000 obyvatel (Strnad 1889, 252). Město samotné zabírá plochu asi $530 \times 460$ metrů, tedy zhruba 21 hektarů.

Koncentrace takového počtu obyvatel na poměrně malém prostoru pưsobila řadu problémů. Jedním z nich zřejmě byla produkce dostatečného množství potravin. Stejně jako v jiných městech je možné také v Plzni předpokládat, že v období po založení města si měštané museli zajistit potraviny soběstačně, pomocí živočišné i rostlinné výroby. Tato situace se zřejmě poměrně záhy začala měnit, s určitými omezeními však tato tradice soběstačnosti pokračovala i v dalším průběhu pozdního středověku (Hoffmann 2009, 236).

\section{Prameny k poznání produkce potravin v pozdně středověké Plzni}

Dlouholetý archeologický výzkum studní a odpadních jímek související především se sanačními úpravami prostor plzeňského podzemí umožnil vytvoření kvantitativně i kvalitativně výrazného nálezového fondu. Rozbor nálezů získaných ze zásypu odpadních jímek obecně přináší cenné poznatky k dějinám každodennosti (Iggers 2002, 95-111) a to se potvrdilo i v možnostech rekonstrukce života $\mathrm{v}$ domácnostech pozdně středověké a raně novověké Plzně (Dudková-Orna 2009; 2013; Orna-Dudková 2016). Proto byla provedena revize sbírkového fondu historické archeologie oddělení starších dějin Západočeského muzea v Plzni s cílem vyhledat 


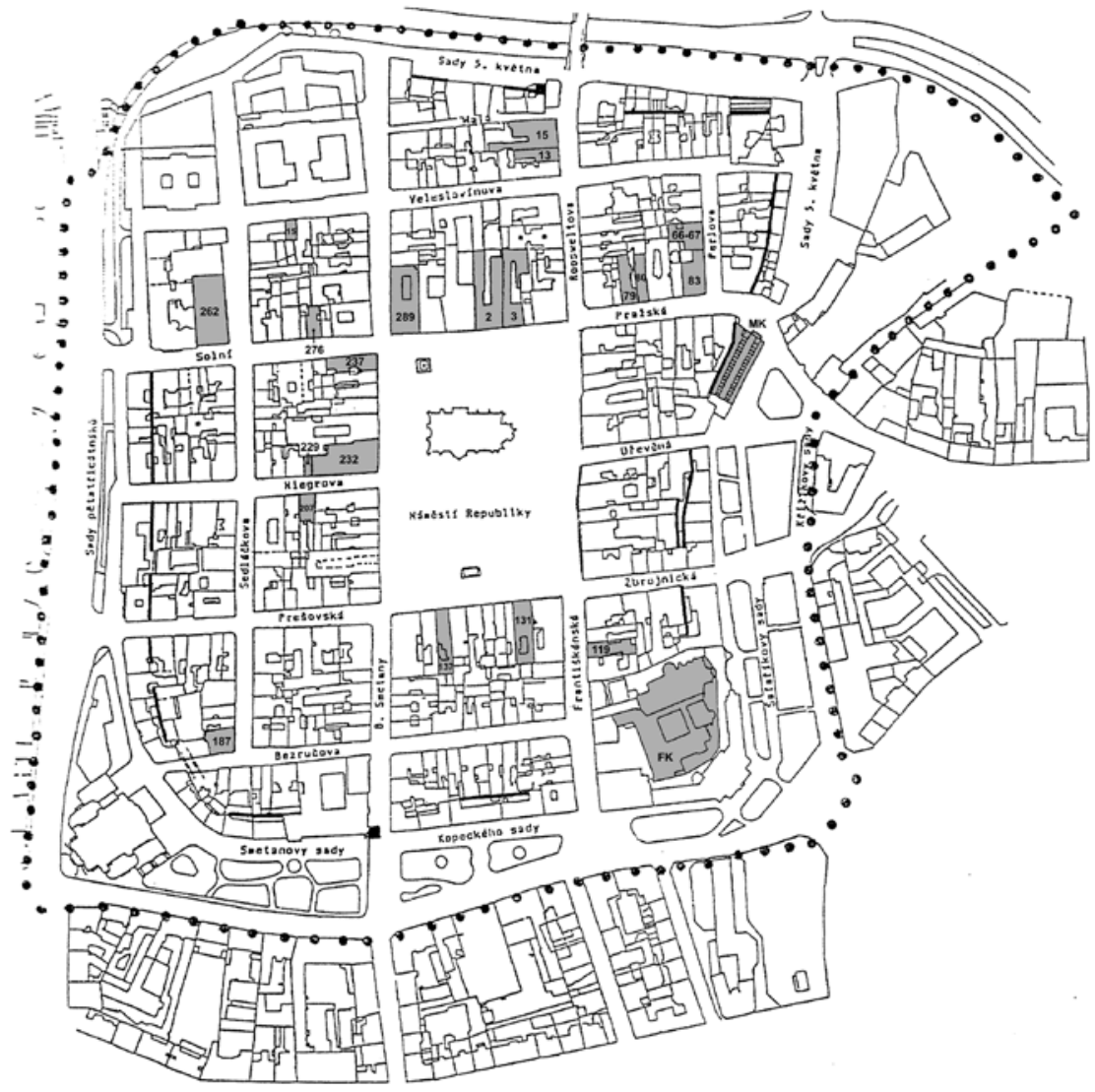

Obr. 1. Celkový plán historického centra s vyznačením čp. lokalit uvedených v textu. MK - Masné krámy, FK - františkánský klášter. Úprava Lenka Ornová.

Abb. 1. Gesamtplanskizze des historischen Zentrums mit eingezeichneten Konskriptionsnummern der im Text auftgeführten Fundstellen. MK - Fleischbänke, FK - Franziskanerkloster. Bearbeitung Lenka Ornová.

artefakty získané ze zásypu odpadních jímek, které mohou dokládat produkci potravin na sklonku středověku v Plzni.

V zásypu odpadních jímek se vyskytují také ekofakty, které jsou pro poznání produkce potravin pozdně středověkého města velmi významným pramenem. Pro potřeby této studie byly využity především v literatuře prezentované výsledky rozborů environmentálních pramenů, které bylo možné dát do souvislosti s archeologickými doklady produkce potravin - artefakty a publikovanými nálezovými situacemi.

Archeologie se při zkoumání vrcholného středověku a následných mladších období neobejde bez písemných pramenů a historických výzkumů. Sociální strukturu středověké a časně novověké Plzně se snaží přiblížit hned několik historiografických studií (Strnad 1909; Macháček 1931; Bělohlávek 1950; Bělohlávek a kol. 1965; Bělohlávková 1989) vycházejících z dochovaných písemných pramenů. Problémem je neúplné dochování těchto pramenů pro dějiny města právě $\mathrm{v}$ období pozdního středověku, $\mathrm{z}$ kterého pochází nejvíc nálezů v odpadních jímkách. Dále se jen zř́íka pamětní knihy, berní prameny, závěti a různá statuta dochovají v ucelených řadách. Při absenci kritického přijímání informací může dojít při jejich interpretaci ke zkreslení (Nováček 2000, 27). Každopádně teprve propojení a komparace archeologických a historických 
pramenů umožňuje relativně komplexní poznání každodenního života v pozdně středověkém městě. $\mathrm{V}$ případě studia potravinářské produkce jsou pak velmi důležitým zdrojem poznání i již zmiňované environmentální rozbory, které analyzují a interpretují velmi široké spektrum ekofaktů.

\section{Archeologické doklady zemědělství nalezené uvnitř města}

\section{Kurníky}

Maximální podíl převážně zemědělského obyvatelstva v předhusitské Plzni bývá odhadován na třetinu (Bělohlávek a kol. 1965, 47). Zásobování masem zřejmě již od založení města zajištovaly masné krámy postavené u Pražské brány na východní straně města (Macháček 1923, 24). Skutečnost, že měšt’ané kupovali již naporcované a částečně vykostěné maso, naznačují výsledky archeozoologické analýzy nálezů z jímky v Perlové ulici čp. 66-67 (Sůvová 2007, 150). Přesto u všech profesních a sociálních skupin měštanstva, snad jen s výjimkou městských elit, chov dobytka a drůbeže představoval běžný způsob zajištování potravy. Chov prasat a ovcí ve městě dokládají městská ustanovení z let 1497 a 1502 (Strnad 1905, 378, 436). Z roku 1424 je doložena funkce městského pastýře (Nováček a kol. 2014, 163). Chov zvířat na parcelách potvrzují také archeologické nálezy. Doklady kurníků ze 14. století se podařilo objevit na parcelách čp. 187 (Nováček 2000, 7) a čp. 131. Kurník na dvorku čp. 131 před polovinou 14. století nahradila vícedílná pletená stavba omazaná hlínou, jejíž určení k chovu domácího zvířectva potvrdila fosfátová analýza (Nováček-Široký 2004, 29). Konzumaci domácího ptactva dokládají archeozoologické analýzy nálezů z jímek v Perlové ulici čp. 66-67 (Sůvová 2007, 149, tab. 1) a Solní ulici čp. 262 (Beneš 1976, 147, 150, 151), a také proteiny identifikované při analýze potravinových zbytků na pozdně středověké keramice z Plzně, dosvědčující vaření nebo dušení drůbežího masa (Pavelka-Orna 2011, 95, 96, tab. 1). K oběma objektům, u kterých byly odkryty doklady kurníků, neexistují zprávy o jejich majitelích v období 14. století. Prvním doloženým majitelem čp. 187 je až na počátku 15. století soukeník Mikuláš Schrollentritt (Strnad 1909, 66), dům čp. 131 patřil až do roku 1407 městskému písaři Svatoslavovi (Strnad 1909, 65).

\section{Vidle}

Další doklady zemědělské činnosti v prostoru města Plzně se podařilo získat ze zásypu odpadních jímek. Hnojné vidle s poškozenou třízubou vidlicí se špicemi okovanými železnými hroty (obr. 2) byly součástí odpadní jímky u domu čp. 137 na náměstí Republiky. Byly vyrobeny z vrbového dřeva s výjimkou př́íček, $\mathrm{k}$ jejich výrobě byl použit javor klen (Orna 2000). K poškození vidlí mohlo dojít při částečném čištění odpadní jímky. Na základě rozboru celých keramických nádob získaných ze zásypu této jímky je možné nález zařadit nejspíše do první poloviny 15. století (Orna a kol. 2011, 99-166). V té době byly postupně vlastníky objektu Johánek z Týna (do 1414), Šimon z Doudlevec (do 1415) a krejčí Předbor (Strnad 1909, 65).

Pracovní část vidlí z jedlového dřeva s třízubou vidlicí (Orna 2000; obr. 3), určených nejspíše pro manipulaci se senem, byla vyzvednuta z odpadní jímky u domu čp. 289 na rohu náměstí Republiky a Dominikánské ulice. Podobně jednoduše vyrobené vidle, pouze v dvojzubé variantě, byly nalezeny při výzkumu hradu ve Veselí nad Moravou (Hoch-Dejmal 2014, 260, tab. $1.1,262)$. Přestože autor archeologického výzkumu předpokládá ukládání zásypu do odpadní jímky zhruba od poloviny 16. do druhé poloviny 17. století (Frýda 1983), několik nádob nasvědčuje jejímu využívání již v období pozdního středověku (Orna a kol. 2011, 99-166). První písemná zmínka o domu je až z roku 1412, kdy byl tento veliký rožní dům v držení Jakuba Jesenického (Strnad 1909, 77). Po něm nemovitost zdědil roku 1427 jeho syn řezník Bartl Pšenička. V roce 1515 prodala dům Důra Pšeničková za 220 kop řezníkovi Vincenci Rajskému z Dubnice. V roce 1583 se majitelkou stala Judyta Rajská z Hyršova (Macháček 1931, 123).

Manipulaci se senem, hnojem a stelivem v pozdně středověké Plzni, pro kterou byly využívány uvedené vidle, dokládají nálezy druhů travnatých společenstev v odpadních jímkách 


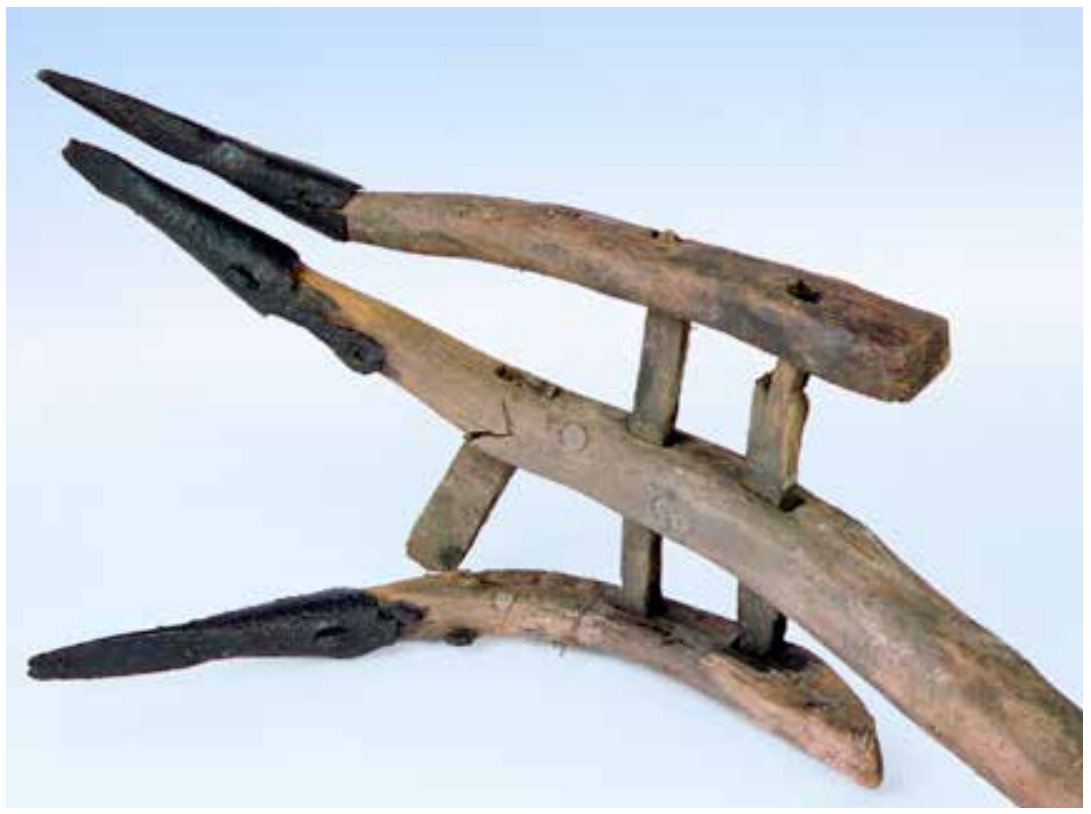

Obr. 2. Plzeň, čp. 137, odpadní jímka, hnojné vidle - detail pracovní části. Rozměry: celková délka $195 \mathrm{~cm}$, rozměry pracovní části $43 \times 23 \mathrm{~cm}$. Podle Orna 2000 .

Abb. 2. Pilsen, Konskr.-Nr. 137, Abwassergrube, Mistgabel - Detail des Arbeitsteils. Abmessungen: Gesamtlänge $195 \mathrm{~cm}$, Abmessungen des Arbeitsteils $43 \times 23 \mathrm{~cm}$. Nach Orna 2000 .

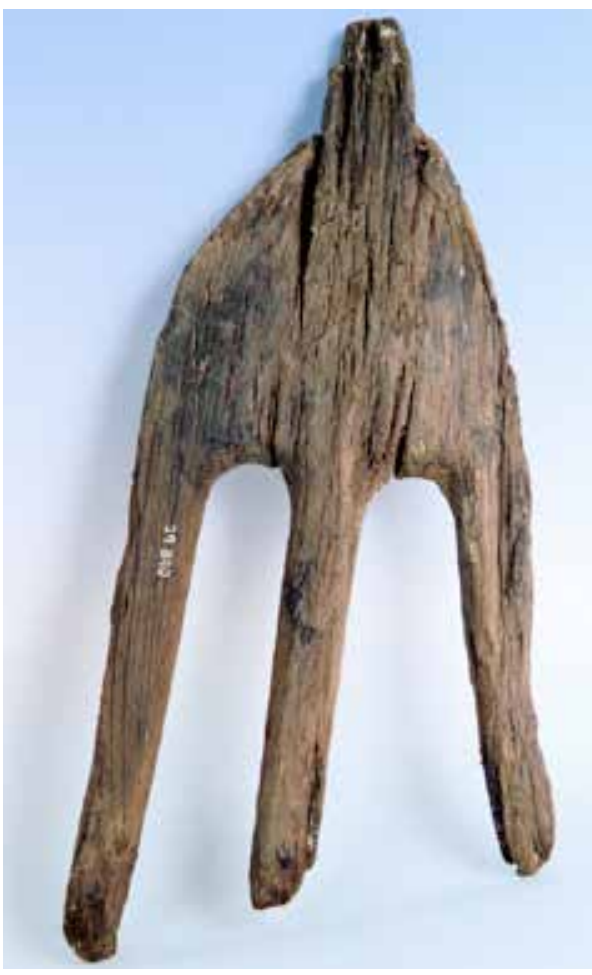

(Schneiderwinklová a kol. 2008, 193) i ve vrstvách při plošných archeologických odkryvech (Nováček-Kočár 2013, 73).

\section{Biják cepu}

Součástí zásypu odpadní jímky, která patřila k domu čp. $276 \mathrm{v}$ Solní ulici, byl biják cepu vyrobený z jabloňového dřeva (Orna 2000; obr. 4). Vzhledem k tomu, že tato ulice byla ve stř̌edověku nazývána Kolářskou ( platea rotificum; Strnad 1909, 71) a čp. 276 i sousední čp. 277 a čp. 278 byly v období pozdního středověku majetkem kolářů Matěje, Hodla a Hurtíka (Strnad 1909, 75), je otázkou, zda nález není spíše dokladem výroby tohoto zemědělského nástroje. $O$ tom, že ve městě našel tento zemědělský nástroj užití, svědčí závět' Václava z Manětína z 15. prosince 1415, ve které je zmíněn mlatec Petr (Petre trituratoris; Strnad 1891, 276).

Obr. 3. Plzeň, čp. 289, odpadní jímka, pracovní část senných vidlí. Rozměry: délka $40 \mathrm{~cm}$. Podle Orna 2000.

Abb. 3. Pilsen, Konskr.-Nr. 289, Abwassergrube, Arbeitsteil einer Heugabel. Abmessungen: Länge $40 \mathrm{~cm}$. Nach Orna 2000. 


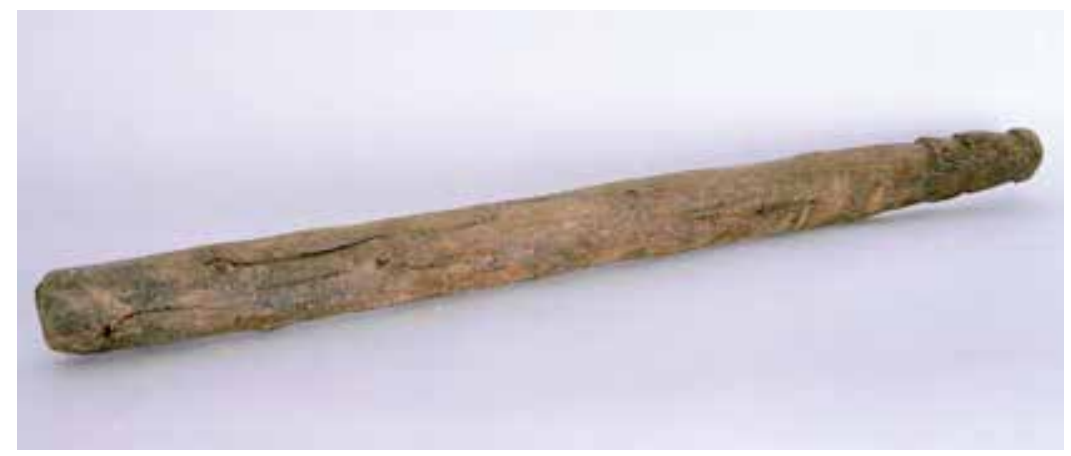

Obr. 4. Plzeň, ěp. 276, odpadní jímka, biják cepu. Rozměry: délka $65,5 \mathrm{~cm}$, max. průměr $5 \mathrm{~cm}$. Podle Orna 2000.

Abb. 4. Pilsen, Konskr.-Nr. 276, Abwassergrube, Dreschflegelprügel. Abmessungen: Länge 65,5 cm, max. Durchmesser $5 \mathrm{~cm}$. Nach Orna 2000.

\section{Archeologické doklady zemědělství nalezené v hospodářském zázemí města}

Městská elita zřejmě již od počátku 14. století provozovala zemědělství ve dvorech na předměstích nebo v širším okolí města. To umožnilo využití domu v městském jádru pouze $\mathrm{k}$ bydlení (Nováček a kol. 2014, 163), potraviny zde byly zřejmě pouze skladovány a připravovány pro konzumaci. Právě ve vesnickém zázemí Plzněl se podařilo archeologicky doložit existenci chmelnice. Př́i výzkumu zaniklé vesnice Roudná na severovýchodním okraji dnešní Plzně byla odkryta koncentrace kůlových jam, které byly interpretovány jako chmelnice (Metlička-Uherský 2003, 5). Písemné zprávy informují o jejich zřízení v tomto prostoru v letech 1555 a 1563 (Sedláček 1937, 242). Další chmelnice písemné zprávy lokalizují do Lobez (Strnad 1905, 112) a směrem k Lobzům (Strnad 1905, 446), Lochotína (Strnad 1891, 239), Skvrňan (Strnad 1891, 113; 1905, 242), pod Homolku (Strnad 1905, 412), pod kostel sv. Mikuláše (Strnad 1905, 736) a ke kostelu Všech Svatých, kde byla špitálská chmelnice (Strnad 1905, 596). Podle nařízení města z roku 1493 pak zpracování chmele mělo probíhat mimo město (Strnad 1905, 320). Nalezené nažky chmele otáčivého v zásypu odpadní jímky v Perlové čp. 66-67 (Schneiderwinklová a kol. 2008, 191) a v sedimentech zkoumaného př́ikopu městského opevnění v prostoru komplexu Pražské brány (Široký a kol. 2008, 289) jsou u druhé lokality řazeny do koření. Chmel je pro toto období také označován jako pochutina a zároveň léčivá droga (Čulíková 2002, 137). Patří mezi komodity, které byly zmiňovány v závětech plzeňských měštanů. Prokop Reš odkázal 29. prosince 1476 „puol chmele letošního“ (Strnad 1905, 192). V závěti Petra Zaječího z 8. března 1491 je uveden dluh půldruhé kopy kbelců chmele (Strnad 1905, 279, 280). O chmelu je zmínka i v závěti Václava Hodoně ze 4. dubna 1521 (Strnad 1905, 701).

\section{Archeologické doklady potravinářských řemesel v pozdně stř̌edověké Plzni}

V Plzni je mezi lety 1400 a 1420 doloženo 46 řemesel. Z potravinářských řemesel jsou zmíněni sladovníci (46 mistrů), řezníci (56 mistrů) a pekaři (30 mistrů; Bělohlávek a kol. 1965, 40-44). Zpřesnění počtu řemesel i řemeslníků se dočkalo období mezi lety 1407-1411, kdy mělo ve městě působit 65 řemesel. Z potravinářských řemesel je zde uvedeno 35 sladovníků, 41 řezníků, 22 pekařů a 19 rybářů (Bělohlávková 1989, 175-179). Z uvedených potravinářských řemesel se přímé archeologické doklady podařilo získat k rybářství a sladovnictví.

1 K vývoji a topografii vesnického zázemí Plzně v pozdním středověku Vařeka-Rožmberský-Holata-Schejbalová 2012; Malivánková Wasková 2015, 14-73. 


\section{Rybářství}

Situování nově založeného města k soutoku řek Radbuzy a Mže jistě znamenalo velký potenciál k získání potravy rybolovem. Dalším vodním tokem, který mohl být pro tento účel využíván, byla Mlýnská strouha. Ta odbočovala z hlavního koryta řeky Radbuzy v jihozápadním rohu městského půdorysu, obtékala město po jeho východní straně a vlila se do Mže. Kanál zřejmě využíval původní hlavní řečiště Radbuzy a již v průběhu druhé poloviny 14. století sloužil jako zdroj vody pro lázně, které zde v období pozdního středověku známe hned troje (Široký 1998, 16). Mlýnská strouha však plnila i další funkce - byla součástí fortifikace města a přiváděla vodu do Velkého neboli Panského mlýna. Při obnově jedné její části archeologický výzkum v roce 2009 nezachytil žádnou výraznější vrstvu sedimentů, lze tedy předpokládat, že voda tekoucí Mlýnskou strouhou v období středověku a časného novověku měla dostatečný průtok a u dna se nevytvářely žádné humózní vrstvy (Orna a kol. 2010). Právě mezi Mlýnskou strouhu a hradby je situována čtvrt' Rybáře, kterou tvořilo třináct domků a je uváděna k roku 1470 (Bělohlávek 1997, 9). Do těchto míst na Špitálském předměstí se rybáři přesunuli po husitských válkách, kdy došlo ke zničení jejich domků za Masnými krámy. Tyto domky byly v majetku rybáŕů - Ondřeje, Jana Rause, Míky Šišky, Martina Měchýře, Vacolda, Vavřince Rieglera a Petra (Strnad 1909, $85,86)$. Jménem známe i rybáře z 15 . století a počátku následujícího věku. Zř́ejmě existovala funkce městského rybáře, Beneš Kotas a jeho dědicové měli za obsazení tohoto postu podle listiny z 26. července 1437 platit kopu grošů ročně svému faráři (Strnad 1891, 392, 393). V závěti z roku 1451 je odkázána částka deset kop grošů rybářce Zuzce (Strnad 1905, 1). V listině z roku 1453 jsou uvedeni rybáři Hašek, Jaklík a Reš (Strnad 1905, 8). Rybář Jan Jaklík je zmíněn ještě ve zprávách z let 1461 (Strnad 1905, 75) a 1503, kde je uveden i rybáŕ Václav (Strnad 1905, 460). V letech 1495 a 1496 je na Špitálském předměstí zmiňován rybář Karf (Strnad 1905, 360, 361). V listině z roku 1503 je uveden rybář Božek (Strnad 1905, 455), v závěti z roku 1505 je zmíněn rybáŕ Hubka (Strnad 1905, 490). Z roku 1510 se dochovala závět’ rybáře Bárty Stehlíka (Strnad 1905, 614).

Na východní straně města za špitálskou zahradou se nacházel ještě rybníček (Strnad 1909, 86). Povolení k jeho zř́zení za chórem františkánského kláštera dostal rybář Trojan 1. května 1347 (Strnad 1891, 68, 69). S tímto rybníčkem zřejmě souvisel i haltýř situovaný za františkánským klášterem, který byl 1. září 1501 postoupen právě františkánům (Strnad 1905, 426, 427).

Obchod s rybami je dokumentován v písemných zprávách, ze sladkovodních je výslovně uveden kapr, candáti a štiky (Strnad 1905, 79, 90). Konzumaci ryb v plzeňských domácnostech dokládají archeozoologické analýzy nálezů ze zásypů odpadních jímek. Výsledky analýz jsou evidentně výrazně determinovány metodou jejich získání. V zásypu odpadní jímky u čp. 262 v Solní ulici byly ručním výběrem nalezeny jen dvě kosti štiky obecné (Beneš 1976, 151). U jímek v Perlové ulici čp. 66-67 bylo díky plavení výplně dvou jímek získáno velké množství kostí ryb - úhoře říčního, parmy říční, štiky obecné, sumce velkého, kapra obecného, cejna velkého, jelce proudníka, plotice obecné, okounovitých, kaprovitých (Sůvová 2007, 149, tab. 1), lipana podhorního, karase obecného, lína obecného, oukleje obecné, hrouzka obecného a ježdíka (Sůvová $2006,255,256$, tab. 1).

V zásypu odpadní jímky přiřazené k domu čp. 80 (Orna-Dudková 2016, 365) byla nalezena vrš pletená z lýka, místy částečně doplněná provazem (obr. 5). Tento dům byl nejpozději v 16. století vlastnictvím ševců (Macháček 1931, 141). Nález tedy může být dokladem samozásobitelského rybolovu. Vyloučit nelze ani variantu, že nějaký rybář zde mohl být v nájemním bydlení (inquilini) v tzv. zadním domě, o kterém první zachovaná zmínka pochází z roku 1407 (Bělohlávková 1989, 171). Nejméně pravděpodobnou se jeví možnost, že vrš byla pro rybáře vyráběna nebo opravována v ševcovské dílně.

Zásypy plzeňských odpadních jímek ukrývaly dřevěné artefakty, jejichž analogie jsou ve stálé expozici Najstarsze karty z dziejów Szczecina (Muzeum Narodowe w Szczecinie - Muzeum Historii Szczecina) prezentovány jako plováky a zátěže sítí. Jde však o interpretaci značně diskutabilní, dřevěná kolečka, ve Štětíně označená jako plováky, jsou zpravidla považována za dětské hračky - kolečka vozíků (Nováček a kol. 2014, 162). Mohly se však používat i jako herní 
kotouče (Müller 1996, Taf. 29:8-11, 24-26, 32, 34, 30:7, 16, 18, 18-21; Klápště ed. 2002, 128, tab. 105:9, 157:11), př́ípadně jako přesleny (Gühne 1991, 43, Abb. 21,3). Co se týče využití dřevěných koulí, které jsou ve Štětíně interpretovány jako zátěže sítí, u nich se v českém a německém prostředí předpokládá, že sloužily spíše ke společenským hrám (Gühne 1991, 43; Richter-Vokolek 1995, 82, tab. 55:8, 126:9; Klápště ed. 2002, 128; Čapek-Militký a kol. 2016, 321, 322), zřejmě jako kuželníkové koule (Nováček a kol. 2014, 162). Na základě ikonografie jsou také řazeny mezi dětské hračky (Mašková 2014, 250). V žádné z plzeňských jímek se nevyskytla výraznější koncentrace těchto nálezů a vyskytují se i jinde než na východní straně města, kde zřejmě sídlila většina rybářů (tab. 1).

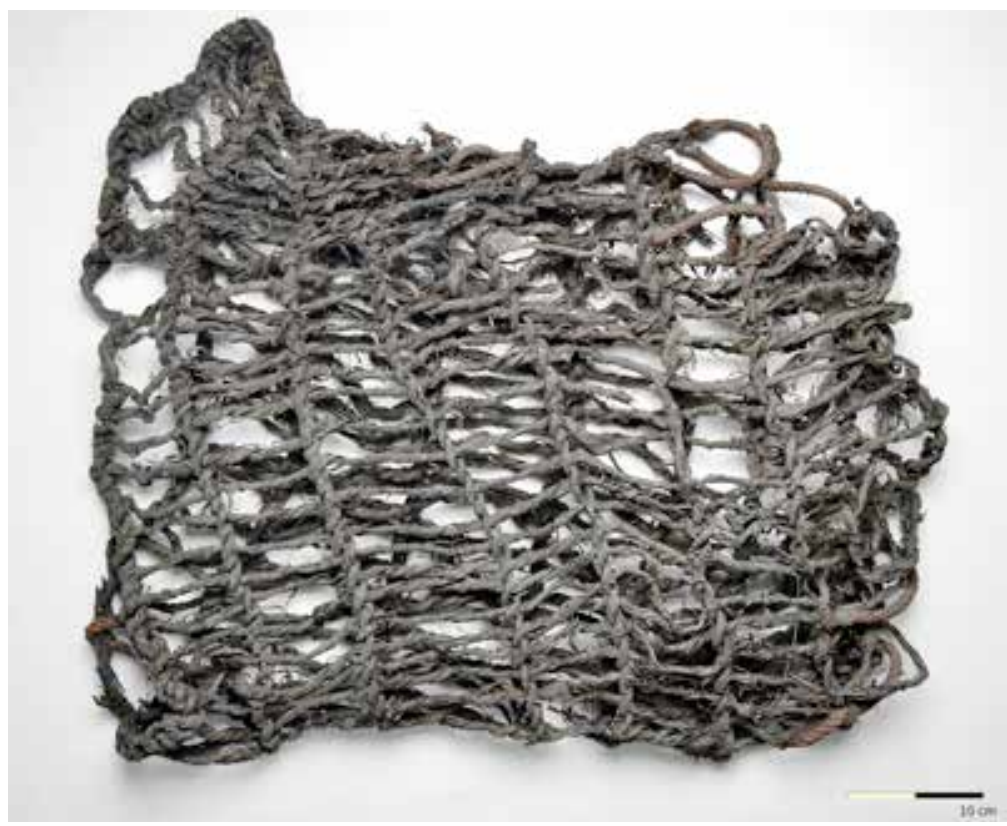

Obr. 5. Plzeň, čp. 80, odpadní jímka, vrš. Rozměry: $61 \times 54 \mathrm{~cm}$. Foto Monika Zemánková.

Abb. 5. Pilsen, Konskr.-Nr. 80, Abwassergrube, Reuse. Abmessungen: $61 \times 54 \mathrm{~cm}$. Foto Monika Zemánková.

\begin{tabular}{|l|l|c|c|}
\hline \multicolumn{1}{|c|}{ předmět } & \multicolumn{1}{c|}{ lokalita } & materiál & rozměry \\
\hline kolečko & Plzeň, čp. 2/3, odpadní jímka & jedle & $\varnothing 9 \mathrm{~cm}$ \\
\hline kolečko & Plzeň, čp. 15, odpadní jímka & jedle & $\varnothing 8,8 \mathrm{~cm}$ \\
\hline kolečko & Plzeň, čp. 34/35, odpadní jímka & jedle & $\varnothing 10 \mathrm{~cm}$ \\
\hline kolečko (zlomek) & Plzeň, čp. 119, odpadní jímka 4 & jedle & $9 \times 3,4 \mathrm{~cm}$ \\
\hline kolečko & Plzeň, čp. 207, odpadní jímka & jedle & $\varnothing 8,8 \mathrm{~cm}$ \\
\hline kolečko (zlomek) & Plzeň, čp. 232, odpadní jímka 2 & jedle & $5,8 \times 2 \mathrm{~cm}$ \\
\hline kolečko & Plzeň, čp. 276, odpadní jímka 2 & smrk & $\varnothing 5 \mathrm{~cm}$ \\
\hline koule & Plzeň, čp. 79, odpadní jímka & javor babyka & $\varnothing 4,5 \mathrm{~cm}$ \\
\hline koule (vrchlík) & Plzeň, čp. 83, odpadní jímka 2 & borovice & $11 \times 5,2 \mathrm{~cm}$ \\
\hline koule & Plzeň, čp. 137, odpadní jímka & bř́́za & $\varnothing 6 \mathrm{~cm}$ \\
\hline koule & Plzeň, čp. 232, odpadní jímka 2 & buk & $\varnothing 12 \mathrm{~cm}$ \\
\hline
\end{tabular}

Tab. 1. Nálezy koleček a koulí v plzeňských odpadních jímkách.

Tab. 1. In Pilsener Abwassergruben gemachte Funde von Rädchen und Kugeln. 


\section{Sladovnictví}

Král Václav II. při založení města udělil 260 plzeňským měštanům várečné právo. V počátcích města zřejmě fungovalo samozásobitelské vaření piva v domácnostech, a to včetně sladování. Nejstarší zpráva o existenci sladovny v Plzni pochází ze 17. dubna 1307, kdy Wolfram Zwinillinger odkázal ke sv. Bartoloměji ,pivovar (braxatorium) a sušírnu svou před městem ležici" (Strnad 1891, 3). Také v odkazech z let 1369 a 1391 jsou sladovny situovány mimo městské hradby, konkrétně na Skvrňanské předměstí na západní straně města (Strnad 1891, 113, 114, 182). Umist'ování sladoven mimo město mělo snižovat riziko požáru, které vyplývalo z jejich dymného provozu. V předhusitské Plzni je doloženo 26 sladoven, ale jejich skutečný počet musel být vyšší (Bělohlávek a kol. 1965, 44-45; Bělohlávková 1989, 178). Postupně si však měštané najímali technologické odborníky. Písemné zprávy z let 1491 a 1495 (Strnad 1905, 289, 355) dokládají v Plzni existenci sladovnického cechu. Mladší z těchto zpráv pak potvrzuje působení

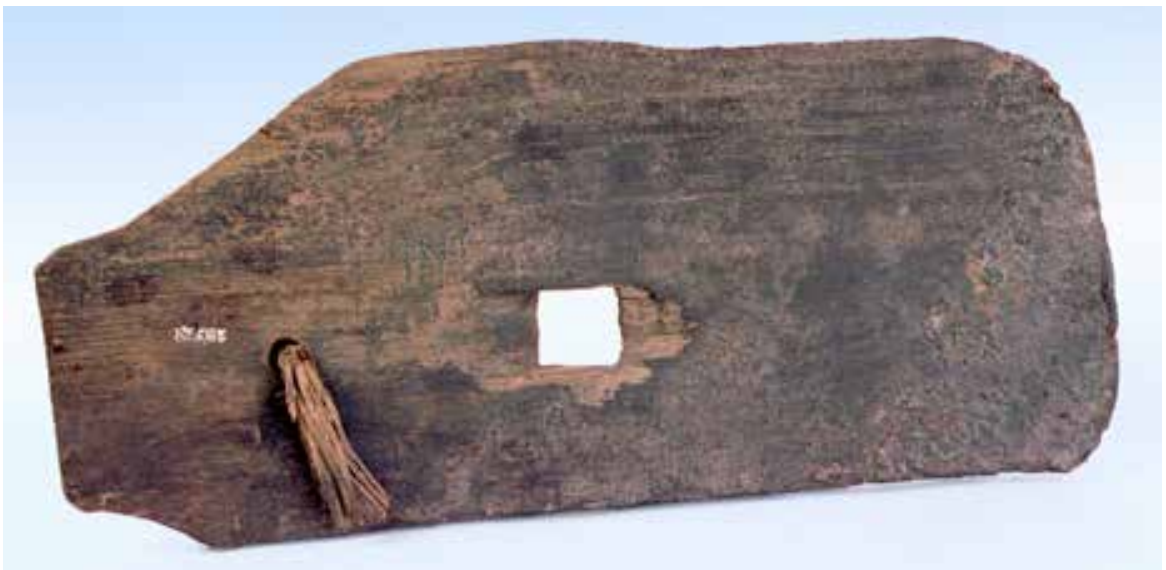

Obr. 6. Plzeň, čp. 83, odpadní jímka 2, sladovnická lopata. Rozměry: 45,5 × $19 \mathrm{~cm}$. Podle Orna 2000.

Abb. 6. Pilsen, Konskr.-Nr. 83, Abwassergrube 2, Malzschaufel. Abmessungen: 45,5 × $19 \mathrm{~cm}$. Nach Orna 2000.

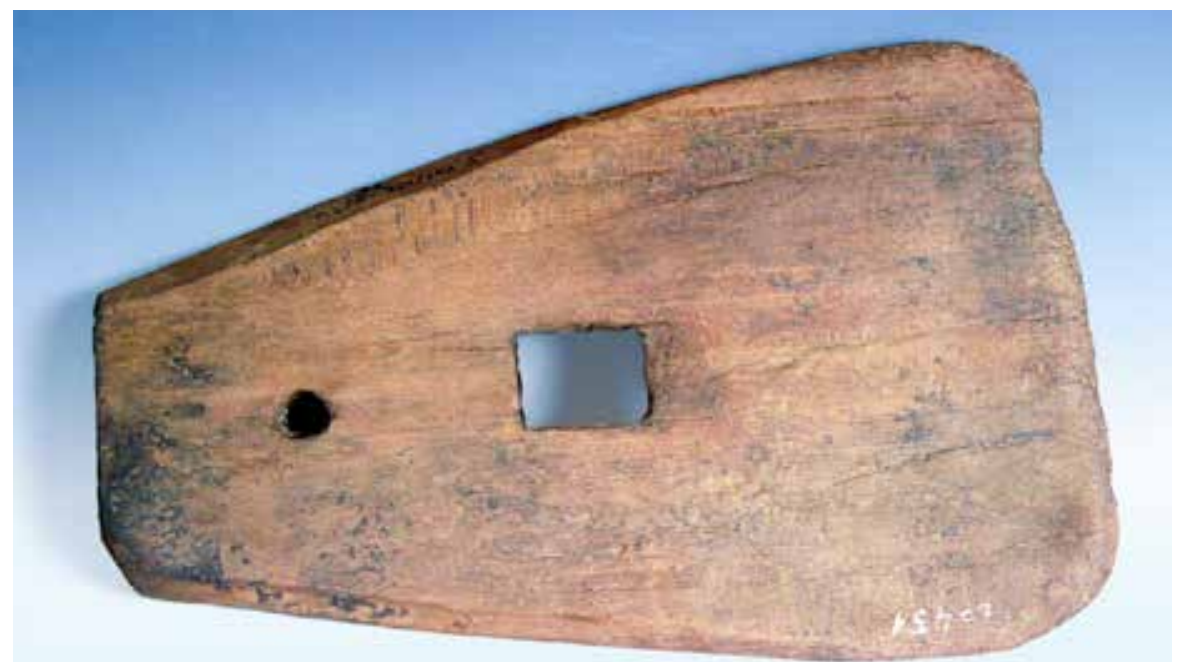

Obr. 7. Plzeň, čp. 80, odpadní jímka, sladovnická lopata. Rozměry: 39 × 23,3-12,5 cm. Podle Orna 2000.

Abb. 7. Pilsen, Konskr.-Nr. 80, Abwassergrube, Malzschaufel. Abmessungen: 39 × 23,3-12,5 cm. Nach Orna 2000. 


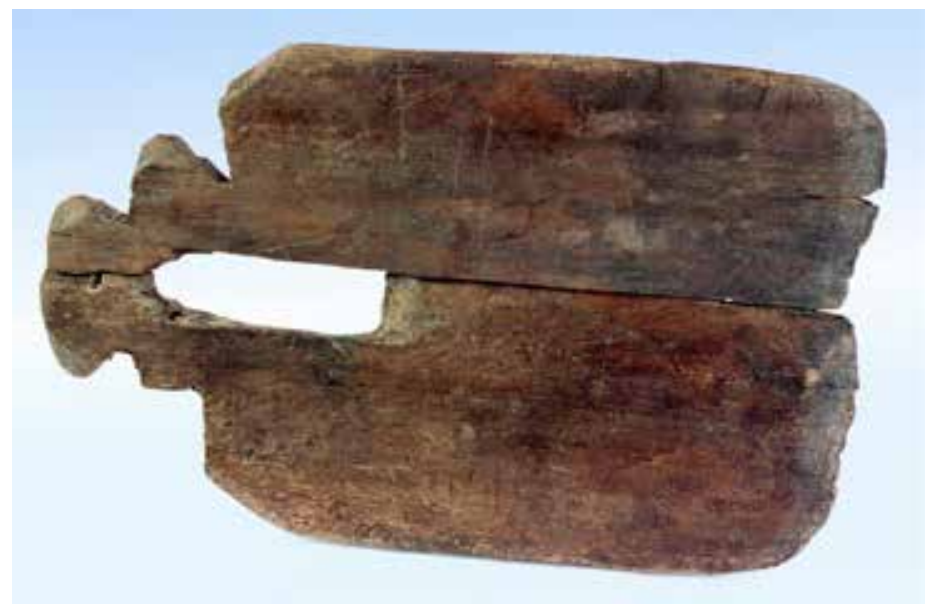

Obr. 8. Plzeň, čp. 137, odpadní jímka, sladovnická lopata. Rozměry: 37,6 × $12 \mathrm{~cm}$. Podle Orna 2000.

Abb. 8. Pilsen, Konskr.-Nr. 137, Abwassergrube, Malzschaufel. Abmessungen: 37,6 × $12 \mathrm{~cm}$. Nach Orna 2000.

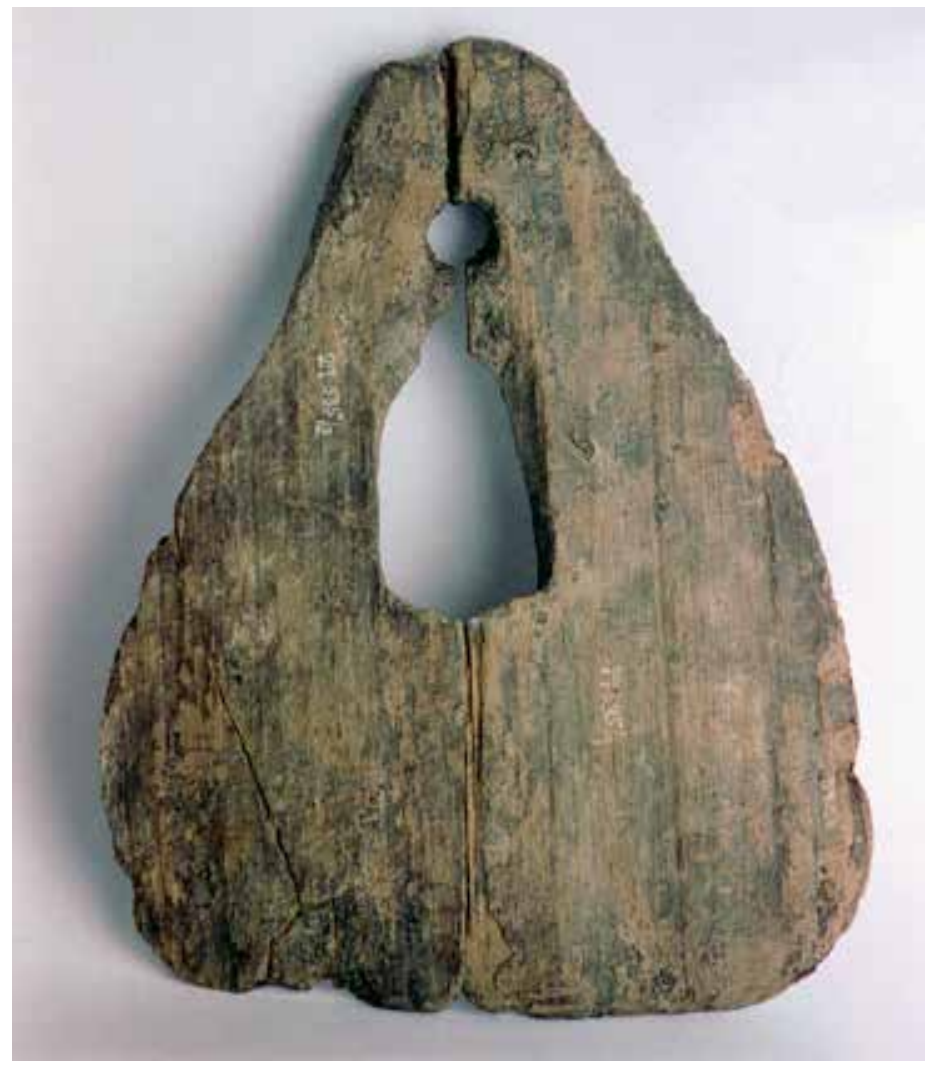

Obr. 9. Plzeň, čp. 237, odpadní jímka, sladovnická lopata. Rozměry: 26,2 × 21-8 cm. Podle Orna 2000.

Abb. 9. Pilsen, Konskr.-Nr. 237, Abwassergrube, Malzschaufel. Abmessungen: 26,2 2 21$8 \mathrm{~cm}$. Nach Orna 2000. 
technologických odborníků - nájemných sladovníků, kteří si pronajímali sladovny (Strnad 1905, 354, 355). Ti jsou uvedeni také v artikuli konšelů a starších obecních z 2. záŕí 1493 (Strnad 1905, $320,321)$. V písemných pramenech je možné dohledat i jména sladovníků. V roce 1453 je uveden Petr Karkoš (Strnad 1905, 9), roku 1459 Mareš (Strnad 1905, 42), v roce 1461 Filip, Petr Chrt a Jan Kútský (Strnad 1905, 73-75), v letech 1464 a 1477 Přech (Strnad 1905, 101, 194) a roku 1464 Ondrášek (Strnad 1905, 102). Sladovník Bláha (Blažej), který byl rychtářem, je zmíněn v písemných zprávách z roku 1487 (Strnad 1905, 251, 254). Ze závěti z roku 1491 je znám Říha Črvenka (Strnad 1905, 279, 280). V letech 1491 a 1492 je jmenován Duchek (Strnad 1905, 282, 300, 301, 310), v roce 1492 pak Václav, Lukáš a Špaček (Strnad 1905, 294, 295, 298). V letech 1505 a 1510 je zmíněn Ješek (Strnad 1905, 526, 614), v roce 1505 Kubík (Strnad 1905, 528, 529), roku 1520 Martin (Strnad 1905, 694), v letech 1521 a 1524 Matouš (Strnad 1905, 704, 737) a v roce 1523 Vít (Strnad 1905, 716).

V zásypech odpadních jímek byly nalezeny pracovní části nástrojů, které na základě analogií vystavených ve stálé expozici Pivovarského muzea v Plzni byly interpretovány jako sladovnické lopaty. K nálezu sladovnické lopaty došlo také při výzkumu nádvoří radnice v Českých Budějovicích, ta však nemohla být zahrnuta do publikace věnované vyhodnocení výzkumu (Čapek-Militký a kol. 2016, 373). Všechny sladovnické lopaty nalezené v Plzni mají obdobnou konstrukci - pracovní část lichoběžného nebo obdélného tvaru vyrobená z bukového dřeva (Orna 2000) byla opatřena dvěma otvory. Větší z nich sloužil k zasunutí násady, menší pak k lepšímu uchycení násady pomocí houžve. Tento fakt dokládá její zachování u exempláře nalezeného v odpadní jímce 2 u čp. 83 (obr. 6). Další sladovnické lopaty byly získány z jímek u čp. 80 (obr. 7), čp. 137 (obr. 8) a čp. 237 (obr. 9). Na základě rozboru celých keramických nádob (Orna a kol. 2011, 99-166) lze ukládání zásypu do odpadních jímek u čp. 80 a 83 předpokládat od poloviny 14. do poloviny 15. století, čp. 137 do první poloviny 15 . století a u čp. 237 na přelom 14. a 15. století. Přímo u těchto domů postrádáme zprávy, že by jejich součástí byla sladovna nebo byly ve vlastnictví sladovníka. U objektů čp. 83 a 80 se zprávy vztahují k sousedním nemovitostem, dům čp. 82 patřil do roku 1413 sladovníku Janovi (Strnad 1909, 80), u čp. 66 se připomíná sladovna (Macháček 1931, 135). Nalezené části sladovnických lopat lze tedy nejspíše spojit se samozásobitelským sladováním. U čp. 83 by tomu nasvědčovaly silněji upražené obilky žita, které zřejmě měly sloužit jako pochutina $\mathrm{k}$ přípravě nápoje, a byly také vyzvednuty ze zásypu odpadní jímky 2 (Holý 1970, 3, 10). Žito mělo zřejmě v tomto období v Plzni a okolí dominantní úlohu (Široký a kol. 2008, 285). Pivo, které obsahuje vysoký podíl žita, je tradiční v Německu, především pak v Bavorsku, a prvně je zaznamenáno římským historikem Tacitem.

\section{Environmentální prameny k produkci potravin v pozdně středověké Plzni v komparaci s písemnými zprávami}

Při poznání produkce potravin na základě nálezů ze zásypů odpadních jímek hrají velmi významnou roli ekofakty. Archeologickým výzkumem prošlo v Plzni v uplynulých padesáti letech přibližně 120 zasypaných studen a odpadních jímek, nálezy se podařilo získat zhruba v 80 z nich. Bohužel je nutno konstatovat, že vzorky výplně byly k archeozoologické a archeobotanické analýze předloženy pouze u několika mála zkoumaných zahloubených objektů.

Je trochu paradoxem, že nejvíce rozborů proběhlo u odpadních jímek zkoumaných ještě v 60. letech 20. století. V rámci zpracování výzkumu jímek v Solní ulici čp. 262 proběhl rozbor archeobotanický (Opravil 1976) i archeozoologický (Beneš 1976). K analýze rostlinných zbytků byla předložena jen malá část výplně (Opravil 1976, 140). Další archeobotanický rozbor proběhl u jímek zkoumaných u čp. 79, 80, 83 a 232 (Holý 1970). K rozboru bylo předloženo jedenáct vzorků, každý z nich měl objem 1-1,51 (Holý 1970, 1). Přestože v dalších dvou desetiletích bylo zkoumáno množství odpadních jímek, neproběhla u jejich výplně žádná př́írodovědná analýza. To se mění až v druhé polovině 90 . let 20. století, kdy proběhly u jímky čp. 97 naprríklad parazitologické rozbory sedimentů (Nováček-Široký 2004, 29). Tato situace se výrazně mění v dalším desetiletí, kdy jsou publikována zjištění získaná při výzkumu odpadní jímky u čp. 66-67 
v Perlové ulici (Schneiderwinklová a kol. 2008; Sůvová 2006; 2007). Výsledky př́rodovědných analýz byly představeny také v rámci publikací výzkumů v Sedláčkově ulici (Široký a kol. 2007) a průzkumu zásypu př́ikopu u Pražské brány (Široký a kol. 2008). Rozborem prošly také potravinové zbytky na stěnách keramických nádob nalezených v odpadních jímkách (Pavelka-Orna 2011).

Environmentální prameny zcela jistě přibližují výživu obyvatel města Plzně v období pozdního středověku. U jímek je však nutné zohlednit i socioekonomický status majitelů domu, ke kterému odpadní objekt patřil. To umožňuje rekonstruovat prostředí a výživu v rámci konkrétní domácnosti, otázkou zůstává reprezentativnost této rekonstrukce, kterou nelze plnohodnotně použít na celé město. Ukázalo se však, že řadu informací z environmentálních pramenů je možné porovnat a doplnit výpovědí písemných zpráv ze sledovaného období.

\section{Obilniny}

Podle ustanovení z roku 1497 se obilí mělo kupovat pouze na trhu na náměstí (Strnad 1905, 378). V závětích z let 1459, 1466, 1474, 1477, 1492, 1495, 1497, 1502, 1515, 1516, 1520, 1521, 1523, 1524 a 1525 je v okolí Plzně doloženo pěstování žita, ovsa a ječmene (Strnad 1905, 45, 46, 118, 183, 195, 294, 300, 303, 338, 355, 376, 436, 664, 694, 696, 704, 723, 736, 743, 759). V odpadních jímkách je nalézáno poměrně malé množství zbytků obilnin, nebot' obilky se špatně dochovávají, pokud nejsou zuhelnatělé, a v domácnostech se zpravidla využívá především obilí upravené mletím, více průkazná je v tomto př́ípadě pylová analýza (Schneiderwinklová a kol. 2008, 190, 191). Pyl obilnin běžně ulpívá i na povrchu obilek, které se následně využívají pro přípravu pokrmů - moučných jídel (Schneiderwinklová a kol. 2008, 190, 194). Proto pylové analýzy dokládají výskyt obilovin i mimo odpadní jímky (Nováček-Kočár 2013, 71; Široký a kol. 2007, 104, 112; 2008, 285). Rozbory potvrzují sortiment uvedený v písemných zprávách, tedy výskyt žita setého, ječmene obecného a ovsa setého (Holý 1970, 3; Opravil 1976, 141; Schneiderwinklová a kol. 2008, 190). Ty nemusely sloužit pouze jako potraviny, ale také ke krmení hospodářských zvířat (Nováček-Kočár 2013, 71). V odpadní jímce u čp. 66-67 byl zaznamenán zvýšený výskyt prosa, které bylo zřjejmě zpracováváno přímo v domácnostech, jak dokládá i výskyt pluch (Opravil 1976, 141; Schneiderwinklová a kol. 2008, 190).

$\mathrm{V}$ potravinových zbytcích na pozdně středověké keramice nalezené v odpadních jímkách byl identifikován gluten, který dokládá využití obilnin. Ty sloužily především k př́ípravě bezmasé stravy založené na mouce a vodě, $v$ jenom př́ípadě vodu nahradilo kozí mléko (Pavelka-Orna 2011, 95, 96).

\section{Ovoce}

Ovoce bylo pěstováno v sadech, které je možné situovat na předměstí do vesnického zázemí Plzně. Několik sadů se podařilo přesněji lokalizovat pomocí písemných pramenů, konkrétně před Malickou bránu (Strnad 1905, 214), do vsi Skvrňany (Strnad 1905, 17) a na cestu k Lobzům (Strnad 1905, 446). Podle písemných zpráv z let 1461, 1462 a 1497 se ovoce prodávalo na trhu (Strnad 1905, 80, 90, 93, 379). Při rekonstrukci pomologie pozdně středověké Plzně byly do pěstovaného ovoce zařazeny třešeň ptačí, višeň, slívy, jabloň, hrušeň a ořešák královský (Holý 1970, 2, 3; Opravil 1976, 141, 142, 144; Schneiderwinklová a kol. 2008, 191; Široký a kol. 2008, 289). Převládající plody peckovin patrně souvisí s jejich zpracováním na povidla, štávy a alkoholické nápoje (Schneiderwinklová a kol. 2008, 191).

\section{Vinná réva}

Mezi pěstované ovoce je řazena i vinná réva. Počátky pěstování vína na jižních svazích nad plzeňskými řekami se kladou do období vlády Karla IV. (Zeman 1947, 254). Archeologicky se dosud nepodařilo zachytit žádné přímé doklady vinic. Jejich lokalizaci opět umožňují písemné prameny. První zmínka o vinici, bez přesnějšího upřesnění polohy, je uvedena v závěti lékaře Ješka z 9. srpna 1380 (Strnad 1891, 140). První lokalizovaná vinice se nacházela na místě kostela sv. Mikuláše, který na ní byl vystavěn v roce 1406 (Strnad 1909, 87). Další svahy s hojnými 
vinicemi byly situovány kolem Kunčina Hrádku, jehož držitelem byl před rokem 1415 Jan Vinař (Strnad 1909, 84). K roku 1413 je uváděna vinice u zaniklé vsi Bory (Bělohlávek 1997, 115). Odkaz z roku 1456 zmiňuje vinice u cesty na Litice (Strnad 1905, 29). Podle údajů uvedených v souvislosti se soudní pří mezi městem Plzní a Václavem Točníkem z Křimic z 23. ř́ijna 1484 (Strnad 1905, 230, 231) je další vinice možné předpokládat v prostoru, který dodnes nese pomístní název Vinice. Pecičky révy vinné v množství, které je možné považovat za doklad jejího místního pěstování, se objevily v zásypu odpadní jímky u čp. 262 (Opravil 1976, 142). Evidovány byly také v zásypech odpadních jímek u čp. 79 (Holý 1970, 6), čp. 80 (Holý 1970, 7), čp. 66-67 (Schneiderwinklová a kol. 2008, 191, 192) a čp. 229 (Holý 1970, 5) a také v zásypu př́ikopu městského opevnění v prostoru komplexu Pražské brány (Široký a kol. 2008, 288, 289, 292). Pecičky v odpadních jímkách jsou spíše dokladem konzumace tohoto ovoce v čerstvém a zřejmě i sušeném stavu (Kočár a kol. 2005, 84). Další možné využití vinné révy je popsáno v závěti z roku 1495, kde je zmíněna Uršula, která „víno páli““ (Strnad 1905, 343). V letech 1461 a 1462 je na trhu doložen prodej řeckého vína (Strnad 1905, 79, 90). Je tedy otázkou, odkud bylo víno uvedené v závěti z 26. června 1516, v níž odkázal Pavel Zídek „dvě polausudci vína“ manželce a dcerám (Strnad 1905, 664, 665).

\section{Zelenina}

Také hortikultura byla pravděpodobně soustředěna mimo prostor mezi hradbami královského města Plzně. Písemné prameny uvádějí zahrady obecně před městem (Strnad 1905, 7), na Špitálském předměstí (Strnad 1905, 157), na předměstí na Vídni (Strnad 1905, 194), ve vsi Malice (Strnad 1905, 187), pod kostelem sv. Mikuláše (Strnad 1905, 618, 736) a za Skvrňanským předměstím (Strnad 1905, 738). Uvedena jsou také jména některých zahradníků, v roce 1461 jsou uvedeni Boreš a Koza (Strnad 1905, 75) a roku 1497 Marek (Strnad 1905, 368). Environmentální prameny pak doložily výskyt okurky/melounu, vodního melounu a mrkve seté (Holý 1970, 3; Opravil 1976, 143; Schneiderwinklová a kol. 2008, 191).

\section{Olejniny}

Nálezy velkých agregátů jemné drtě semen konopí jsou pokládány za doklad samozásobitelského lisování olejů (Holý 1970, 3). Konopí seté však mohlo také sloužit jako postní potravina určená pro přípravu semencových kaší a bylo také rostlinou vláknodárnou (Kočár a kol. 2005,78). Mezi další nalézané olejniny patří mák setý a len setý (Holý 1970, 3; Schneiderwinklová a kol. 2008, 191; Široký a kol. 2008, 285). Podle písemných zpráv z let 1461, 1462 a 1500 se olej kupoval i na trhu, kam byl dovážen (Strnad 1905, 79, 90, 91, 765).

\section{Importy}

Stejně jako v jiných českých městech (Čapek-Militký a kol. 2016, 374; Klápště ed. 2002, 200) byly také v Plzni, konkrétně v zásypu odpadní jímky u čp. 66-67, nalezeny nažky fíků (Schneiderwinklová a kol. 2008, 193). Jejich prodej na trhu je doložen v letech 1461 a 1462 (Strnad $1905,79,90)$.

\section{Závěr}

Archeologické doklady potravinářské produkce královského města Plzně v období pozdního středověku s mírným přesahem do časného novověku se podařilo získat různými druhy výzkumů. Plošné záchranné výzkumy na parcelách v intravilánu města odkryly kurníky ze 14. století u čp. 131 a 187, které dokládají chov drůbeže jako běžný způsob zajištění potravy pro domácnosti, alespoň v prvních desetiletích po založení města.

Záchranný archeologický výzkum zaniklé středověké vsi Roudná na severovýchodním okraji dnešní Plzně doložil existenci chmelnice, která je v prostoru již zaniklé osady zmiňována písemnými prameny v letech 1555 a 1563. 
Jako cenná pramenná základna se i v př́ípadě hledání archeologických dokladů potravinářské produkce ukázaly odpadní jímky. Ze zásypu jedné z nich, situované u čp. 137 na náměstí Republiky, se podařilo získat hnojné vidle s poškozenou třízubou vidlicí se špicemi okovanými železnými hroty z první poloviny 15 . století. Senné vidle z jedlového dřeva s třízubou vidlicí byly vyzvednuty z odpadní jímky u domu čp. 289 na rohu náměstí Republiky a Dominikánské ulice. Se samozásobitelským sladováním zřejmě souvisí nálezy pracovních částí sladovnických lopat v zásypu odpadních jímek u čp. 80, čp. 83, čp. 137 a čp. 237. Tyto lopaty lze chronologicky zařadit do období od poloviny 14 . do poloviny 15 . století.

Další dva artefakty nalezené v zásypech odpadních jímek nemusí zcela nutně přímo souviset $\mathrm{s}$ potravinářskou produkcí, může jít spíše o doklady jejich výroby. V jímce, která patřila k domu čp. 276 ve středověku vlastněnému koláři, to byl biják cepu vyrobený z jabloňového dřeva. V zásypu odpadní jímky přiřazené $\mathrm{k}$ čp. 80 byla nalezena vrš pletená z lýka. Vzhledem $\mathrm{k}$ částečnému doplnění částí vrše provazem lze zvažovat $\mathrm{i}$ opravu, $\mathrm{v}$ úvahu však připadá též samozásobitelský rybolov nebo nájemní bydlení. Dům čp. 80 byl nejpozději v 16. století vlastnictvím ševců.

Dokladem rybářství by na základě analogií určených v polském Štětíně jako plováky a zátěže sítí mohly být také dřevěné koule a kolečka. Jejich interpretace na jiných lokalitách však směřuje spíše k dětským a společenským hrám.

Pro poznání produkce potravin na základě nálezů ze zásypů odpadních jímek hrají významnou roli ekofakty. Archeologickým výzkumem prošlo v Plzni v uplynulých padesáti letech přibližně 120 zasypaných studen a odpadních jímek, nálezy se podařilo získat zhruba v $80 \mathrm{z}$ nich. Bohužel je nutno konstatovat, že vzorky výplně byly k archeozoologické a archeobotanické analýze předloženy pouze u několika mála zkoumaných zahloubených objektů.

Výsledky provedených analýz jsou navíc výrazně determinovány metodou získání vzorků. To je možné sledovat u nálezů konzumovaných ryb. V zásypu odpadní jímky u čp. 262 v Solní ulici byly ručním výběrem nalezeny jen dvě kosti štiky obecné, u jímek v Perlové ulici čp. 66-67 bylo díky plavení výplně dvou jímek získáno velké množství kostí ryb - úhoře říčního, parmy ř́iční, štiky obecné, sumce velkého, kapra obecného, cejna velkého, jelce proudníka, plotice obecné, okounovitých, kaprovitých, lipana podhorního, karase obecného, lína obecného, oukleje obecné, hrouzka obecného a ježdíka. Archeozoologické analýzy u témat sledovaných v rámci této studie potvrdily konzumaci domácího ptactva a naznačily, že měštané kupovali již naporcované a částečně vykostěné maso.

Množství peciček révy vinné v zásypu odpadní jímky u čp. 262 se považuje za doklad jejího místního pěstování, které se na jižních svazích nad plzeňskými řekami předpokládá od období vlády Karla IV. Silněji upražené obilky žita vyzvednuté ze zásypu odpadní jímky 2 u čp. 83, které zř̉ejmě měly sloužit jako pochutina k prrípravě nápoje, patrně ukazují na domácí sladování. Nalezené nažky chmele otáčivého jsou dokladem jejich užívání jako koření, pochutiny nebo léčivé drogy.

Environmentální prameny potvrdily výskyt obilnin uváděných v písemných zprávách pro období pozdního středověku v Plzni. Písemné prameny doložily import fíků na plzeňský trh.

\section{Prameny a literatura}

BĚLOHLÁVEK, M., 1950: Sociální rozvrstvení plzeňského obyvatelstva v roce 1470. In: Život Plzeňska I, 134-138, 157-161. Plzeň.

- 1997: Plzeňská předměstí. Plzeň.

BĚLOHLÁVEK, M. a kol., 1965: Dějiny Plzně I. Plzeň.

BĚLOHLÁVKOVÁ, J., 1989: Nejstarší dochovaná plzeňská městská kniha soudní z let 1407-1411, Sborník archivních prací 39, 121-195.

BENEŠ, J., 1976: Osteologický materiál ze středověké studny 1. (Plzeň - Solní ulice č. 20). In: Středověká studna v Plzni - Solní ulici. Archeologické studijní materiály 12 (Nechvátal, B., ed.), 147-151. Praha. 
ČAPEK, L.-MILITKÝ, J. a kol., 2016: Historická radnice v Českých Budějovicích ve světle archeologických výzkumů a rozboru hmotných pramenů. Plzeň - České Budějovice.

ČULÍKOVÁ, V., 2002: Proměny životního prostředí v Mostě podle analýz rostlinných makrozbytků z archeologických situací. In: Archeologie středověkého domu v Mostě (čp. 226) - The archaeology of a medieval House (No. 226) in Most. Mediaevalia archaeologica 4 (Klápště, J., ed.), 136-157. Praha - Most.

DUDKOVÁ, V.-ORNA, J., 2009: A description of medical equipment in the Early Modern period on the basis of finds from the cesspit at house no. 289 in Plzeň - Obraz vybavení lékaře v novověku na základě nálezů z odpadní jímky v domě č. p. 289 v Plzni - Die Ausstattung eines neuzeitlichen Arztes aufgrund der Funde aus Abfallgrube in Konskr.-Nr. 289 in Pilsen, Studies in Post-Medieval Archaeology 3, 501-508.

- 2012: Written sources and archaeological excavations in Pilsen, Náměstí Republiky no. 97. Písemné prameny a archeologický výzkum v Plzni, Náměstí Republiky čp. 97 - Schriftquellen und die archäologische Grabung in Pilsen, Náměstí Republiky Konskr.-Nr. 97, Studies in Post-Medieval Archaeology 4, 419-426.

- 2013: Osobní hygiena v plzeňských domácnostech na sklonku středověku - Die persönliche Hygiene in Pilsener Haushalten zur Neige des Mittelalters, AH 38, 557-568.

FRÝDA, F., 1983: Plzeň čp. 289, Dominikánská 2, studna 1. Nálezová zpráva ulož. v archivu odd. starších dějin ZČM v Plzni, č. j. 189.

GÜHNE, A., 1991: Stadtarchäologie in Freiberg. Holzfunde. Berlin.

HOFFMANN, F., 2009: Středověké město v Čechách a na Moravě. Praha.

HOCH, A.-DEJMAL, M., 2014: Dřevěné provozní vybavení z hradu Veselí nad Moravou - Betriebsausstattung aus Holz von der Burg in Veselí an der March, AH 39, 257-271.

HOLÝ, F., 1970: Archeobotanický výzkum některých středověkých objektů města Plzně, rkp. ulož. v archivu odd. starších dějin ZČM v Plzni.

IGGERS, G. G., 2002: Dějepisectví ve 20. století. Praha.

KLÁPŠTĚ, J., ed., 2002: Archeologie středověkého domu v Mostě (čp. 226) - The archaeology of a medieval House (No. 226) in Most. Mediaevalia archaeologica 4. Praha.

KOČÁR, P. a kol., 2005: Kočár, P.-Klozar, A.-Schneiderwinklová, P.-Kostrouch, F.-Sůvová, Z.-Kočárová, R.-Kyncl, T.-Petr, L.-Hauer, M., Plzeň, čp. 66/67, Perlová 3-5. Nálezová zpráva o záchranném archeologickém výzkumu při odstranění havárie ve sklepích. 2. etapa, rkp. ulož. v ZIP o. p. s., č. j. 318/05.

MACHÁČEK, F., 1923: O staré Plzni. Plzeň.

- 1931: Dvě studie k dějinám Plzně a Plzeňska. Plzeň.

MALIVÁNKOVÁ WASKOVÁ, M., 2015: Formování a vývoj panství města Plzně, Sborník archivních prací 65, 3-98.

MAŠKOVÁ, P., 2014: Archeologie a hračky. In: Přemyslovský dvůr. Život knížat, králů a rytiřů ve středověku (Dvořáčková-Malá, D.-Zelenka, J. a kol., edd.), 249-252. Praha.

METLIČKA, M.-UHERSKÝ, M., 2003: Senec, okr. Plzeň-sever. Zaniklá středověká ves Roudná, stavba rodinného domu, ppč. 1139/1. Předběžná závěrečná zpráva ulož. v archivu odd. starších dějin ZČM v Plzni.

MÜLLER, U., 1996: Holzfunde aus Freiburg/Augustinereremitenkloster und Konstanz. Herstellung und Funktion einer Materialgruppe aus dem späten Mittelalter. Stuttgart.

NOVÁČEK, K., 2000: Středověký dům v Plzni. Archeologický výzkum parcely v Sedláčkově ul. 1 (čp. 187), Sborník ZČM v Plzni - Historie XV, 5-66.

NOVÁČEK, K.-KOČÁR, P., 2013: K počátkům minoritského konventu v Plzni, Forum urbes medii aevi $\mathrm{VII} / 1,64-75$.

NOVÁČEK, K. a kol., 2014: Nováček, K.-Stočes, J.-Široký, R.-Wasková, M., Počátky Nové Plzně a její vývoj do husitství. In: Dějiny města Plzně I. Do roku 1788, 124-186. Plzeň.

NOVÁČEK, K.-ŠIROKÝ, R., 2004: Prvních sto let. Počátky Nové Plzně z pohledu archeologie, Minulostí Západočeského kraje XXXIX, 7-51.

OPRAVIL, E., 1976: Rostliny ze středověkých objektů v Plzni (Solní ulice). In: Středověká studna v Plzni Solní ulici. Archeologické studijní materiály 12 (Nechvátal, B., ed.), 140-146. Praha.

ORNA, J., 2000: Nálezy středověkých dřevěných předmětů z Plzně. Katalog. CD-ROM. Plzeň.

ORNA, J. a kol., 2010: Revitalizace severovýchodní části sadového okruhu města Plzně - Mlýnská strouha, rkp. NZ záchranného archeologického výzkumu ulož. v archivu oddělení starších dějin ZČM, č. j. 25/10.

- 2011: Keramická produkce města Plzně v období 14. a 15. století. Příbram.

ORNA, J.-DUDKOVÁ, V., 2016: Možnosti přiřazení předmětů z odpadních jímek v Plzni konkrétním obyvatelům města - Möglichkeiten, Gegenstände aus Pilsner Abwassergruben bestimmten Bürgern der Stadt zuzuordnen, AH 41, 363-374. 
PAVELKA, J.-ORNA, J., 2011: Výsledky analýzy potravinových zbytků na pozdně středověké keramice z Plzně, Acta Fakulty filozofické Západočeské univerzity v Plzni, 84-99.

RICHTER, M.-VOKOLEK, V., 1995: Hradec Králové. Slovanské hradiště a počátky středověkého města. Hradec Králové.

SEDLÁČEK, A., 1937: Hrady, zámky a tvrze království českého 13. Plzeňsko a Loketsko. 1937. Praha.

SCHNEIDERWINKLOVÁ, P. a kol., 2008: Schneiderwinklová, P.-Kostrouch, F.-Sůvová, Z.-Kočár, P.Kočárová, R.- Kyncl, T.-Klozar, A.-Petr, L., Raně novověká studna z Plzně, Perlové ulice - výpověd' archeologických a environmentálních pramenů - A Renaissance cesspit from Plzeň, Perlová Street results of archaelogical and environmental analyses. In: Ve službách archeologie VIII/2 (Hašek, V.-Nekuda, R.-Ruttkay, M., edd.), 175-196. Brno - Nitra.

STRNAD, J., 1889: Obyvatelstvo královského města Plzně dle jmen a národnosti až do války husitské, PA XIV, 247-252.

- 1891: Listář královského města Plzně a druhdy poddaných osad. Č́st I. Od r. 1300-1450. Plzeň.

- 1905: Listář královského města Plzně a druhdy poddaných osad. Č́st II. Od r. 1450-1526. Plzeň.

- 1909: Nejstarší místopis Plzně do válek husitských, Sborník městského historického musea v Plzni I, 54-87.

SU゚VOVÁ, Z., 2006: Archeozoologická analýza materiálu ze tří pozdně středověkých studen v Plzni. In: Ve službách archeologie VII, 255-259. Brno.

- 2007: Archeozoologické nálezy z pozdně středověké jímky v Perlové ulici v Plzni (metodické zastavení), Sborník ZČM v Plzni - Historie XVII, 148-153.

ŠIROKÝ, R., 1998: Pitná, užitková a odpadní voda v raně novověké Plzni - Wasserversorgung und Entssorgung in Plzeň im frühen Neuzeit, Sborník ZČM v Plzni - Historie XIV, 5-21.

ŠIROKÝ, R.-KAISER, L.-KOČÁR, P.-NOVÁKOVÁ, K., 2007: Sedláčkova ulice v Plzni ve světle archeologického výzkumu. K podobě veřejných prostranství středověkých měst, Forum urbes medii aevi IV, 94-117.

ŠIROKÝ, R. a kol., 2008: Široký, R.-Kočár, P.-Hlaváč, J.-Kaštovská, K.-Kostrouch, F.-Kyncl, J.-Militký, J.-Pokorný, P.-Postránecká, K.-Schneiderwinklová, P., Př́íkop středověkého opevnění města Plzně: archeologický a environmentální výzkum v prostoru zaniklé Pražské brány, Forum urbes medii aevi V. Městské fortifikace ve vrcholně středověkých zeměpanských městech střední Evropy, 272-311.

VAŘEKA, P.-ROŽMBERSKÝ, P.-HOLATA, L.-SCHEJBALOVÁ, Z., 2012: Vesnické zázemí stř̌edověké Nové Plzně - Das dörfliche Hinterland des mittelalterlichen Neu Pilsen, AH 37, 289-335.

VOJTÍŠEK, V., 1920: Z nejstarších právních dějin města Plzně, Sborník Městského historického musea v Plzni 5, 1-84.

ZEMAN, A., 1947: Plzeň v první polovině XVIII. století. Poměry hospodářské a sociální. Plzeň.

\section{Zusammenfassung}

\section{Möglichkeiten der Archäologie zur Erkenntnisgewinnung über die Nahrungsmittelpro- duktion im spätmittelalterlichen Pilsen}

Im Rahmen von verschiedenen Grabungsarten ist es gelungen, für die Lebensmittelproduktion der Königsstadt Pilsen archäologische Belege aus der Zeit des Spätmittelalters mit leichtem Überhang in die frühe Neuzeit zu gewinnen. Bei flächendeckend im Intravillan der Stadt durchgeführten Rettungsgrabungen wurden bei den Konskriptionsnummern 137 und 187 Hühnerställe aus dem 14. Jahrhundert entdeckt, welche die Haltung von Geflügel als gängige Art der Nahrungsmittelgewinnung für Haushalte belegen, zumindest in den ersten Jahrzehnten nach Gründung der Stadt.

Durch die in der mittelalterlichen Dorfwüstung Roudná am nordöstlichen Rand des heutigen Pilsens durchgeführte Rettungsgrabung wurde die Existenz eines Hopfenfeldes belegt, das im Bereich der bereits wüsten Siedlung in den Jahren 1555 und 1563 in den schriftlichen Quellen Erwähnung findet.

Als wertvoller Quellenfundus erwiesen sich bei der Suche nach archäologischen Belegen für die Nahrungsmittelproduktion auch Abwassergruben. In der Verfüllung der bei 
Konskr.-Nr. 137 am Platz der Republik gelegenen Abwassergrube wurde eine Mistgabel mit beschädigtem, aus drei Zinken bestehendem Gabelkopf mit geschmiedeten Eisenspitzen aus der ersten Hälfte des 15. Jahrhunderts entdeckt. Eine Heugabel aus Tannenholz mit einem aus drei Zinken bestehenden Gabelkopf wurde aus der Abwassergrube beim Haus Konskr.-Nr. 289 an der Ecke Platz der Republik und Dominikanerstraße gehoben. Mit dem Mälzen in Selbstversorgung hängen offenbar die in der Verfüllung der Abwassergruben bei den Konskr.-Nr. 80, 83, 137 und 237 gemachten Funde der Arbeitsteile von Malzschaufeln zusammen. Diese Schaufeln lassen sich chronologisch in die Zeit zwischen Mitte 14. bis Mitte 15. Jahrhundert einordnen.

Weitere zwei in den Verfüllungen von Abfallgruben entdeckte Artefakte müssen nicht unbedingt direkt mit der Nahrungsmittelproduktion zusammenhängen, es könnte sich dabei eher um Belege für die Erzeugung von Lebensmitteln handeln. In der zum Haus mit der Konskr.-Nr. 276 gehörenden Grube, deren Eigentümer im Mittelalter ein Radmacher war, handelte es sich um den aus dem Holz eines Apfelbaums hergestellten Prügel eines Dreschflegels. In der Konskr.-Nr. 80 zugeordneten Abwassergrube wurde eine aus Bast geflochtene Reuse entdeckt. Im Hinblick darauf, dass ein Teil der Reuse teilweise mit einem Strick ergänzt wurde, kann man in Erwägung ziehen, dass sie dort repariert wurde, in Betracht kommt jedoch auch Fischfang in Selbstversorgung oder eine Mietwohnung. Haus Nr. 80 befand sich spätestens im 16. Jahrhundert im Besitz von Schustern.

Einen Beleg für den Fischfang könnten aufgrund von Analogien, die im polnischen Stettin als Schwimmer und Netzbeschwerer bestimmt wurden, auch Holzkugeln und -rädchen darstellen. Ihre Interpretation an anderen Fundstellen geht jedoch eher in Richtung von Kinderspielzeug und Gesellschaftsspielen.

Um Erkenntnisse über die Nahrungsmittelproduktion anhand von Funden zu gewinnen, die aus den Verfüllungen von Abwassergruben stammen, spielen auch Ökofakten eine bedeutende Rolle. In den vergangenen fünfzig Jahren wurde in Pilsen bei annähernd 120 verschütteten Brunnen und Abwassergruben eine archäologische Grabung durchgeführt, in ungefähr 80 von ihnen konnten Funde gemacht werden. Leider muss festgehalten werden, dass nur von einigen wenigen untersuchten eingetieften Objekten Proben aus der Verfüllung für eine archäozoologische und archäobotanische Analyse vorgelegt wurden.

Die Ergebnisse der durchgeführten Analysen werden darüberhinaus beträchtlich durch die Gewinnungsmethode der Proben determiniert. Dies kann bei den Funden der konsumierten Fische beobachtet werden. In der Verfüllung der Abfallgrube bei Konskr.-Nr. 262 in der Straße Solní (Salzstr.) wurden durch per Hand erfolgte Entnahme nur zwei Hechtgräten gefunden, bei den Gruben in der Straße Perlová (Perlstr.) Konskr.-Nr. 66-67 konnte dank des Abschlämmens der Verfüllung von zwei Gruben eine große Fülle von Fischgräten folgender Fischarten gefunden werden: Flussaal, Flussbarbe, Hecht, Wels, Karpfen, Zander, Hasel, Plötze, Barschartige, Karpfenartige, europäische Äsche, Karausche, Schleie, Ukelei, Gründling, Kaulbarsch. Die archäologische Analysen, die bei den im Rahmen der vorliegenden Studie beobachteten Themen durchgeführt wurden, haben den Konsum von heimischer Vogelarten bestätigt und angedeutet, dass die Stadtbewohner bereits portioniertes und teilweise ausgebeintes Fleisch gekauft haben.

Die Fülle der Weintraubenkerne aus der Verfüllung der Abwassergrube bei Konskr.-Nr. 262 wird als Beleg für einen örtlichen Rebenanbau angesehen, der an den Südhängen oberhalb der Pilsener Flüsse seit der Regierungszeit Karls IV. angenommen wird. Stärker gedörrter Roggen, der offenbar als Geschmacksstoff zur Getränkezubereitung dienen sollte und aus der Verfüllung von Abwassergrube 2 bei Konskr.-Nr. 83 gehoben wurde, deutet offenbar darauf hin, dass dort zuhause gemälzt wurde. Die gefundenen Ächenen des echten Hopfens sind ein Beleg für ihre Verwendung als Gewürz, Genussmittel oder Heildroge.

Die Umweltquellen haben das Vorkommen der in den schriftlichen Quellen für die Zeit des Spätmittelalters in Pilsen aufgeführten Halmfrüchte bestätigt. In den schriftlichen Quellen ist der Import von Feigen auf dem Pilsener Markt belegt. 
Mgr. Jiří Orna, Západočeské muzeum v Plzni, Kopeckého sady 2, 30100 Plzeň, Česká republika, jorna@zcm.cz

Mgr. Veronika Dudková, Západočeské muzeum v Plzni, Kopeckého sady 2, 30100 Plzeň, Česká republika, vdudkova@zcm.cz 
